\title{
Path Analysis on the Social, Economic, and Cultural Determinants of Male Contraceptive Use in Family Planning Village, Yogyakarta, Indonesia
}

\author{
Bettya Kartikasari'), Ismi Dwi Astuti Nurhaeni²), Rita Benya Adriani3) \\ 1)Masters Program in Public Health, Universitas Sebelas Maret \\ 2)Faculty of Social and Political Science, Universitas Sebelas Maret \\ 3)School of Health Polytechnics Surakarta
}

\begin{abstract}
Background: One of today's global problems is the rapid growth of population. Population growth can be controlled through contraceptive method utilization. However, contraceptive use among males in most developing countries, including Indonesia, remains low. This study aimed to determine the social, economic, and cultural factors affecting male contraceptive use in family planning village, Yogyakarta, Indonesia, using Theory of Planned Behavior (TPB) and path analysis.

Subjects and Method: A case control study was carried out in Yogyakarta, Indonesia. A sample of 200 men aged 15 to 49 years was selected for this study by fixed disease sampling. The dependent variable was male surgical contraceptive method use. The independent variables were age, knowledge, education, intention, attitude, perceived behavior control, subjective norm, social culture, access to health service, and health service quality. The data were collected by questionnaire and analyzed by path analysis.

Results: Male surgical contraceptive method use was directly affected by older age (b = 1.50; 95\% $\mathrm{CI}=0.54$ to $2.46 ; \mathrm{p}=0.002)$, better knowledge $(\mathrm{b}=1.48 ; 95 \% \mathrm{CI}=0.48$ to $2.49 ; \mathrm{p}=0.004)$, stronger intention $(b=1.10 ; 95 \% C I=0.15$ to $2.06 ; p=0.24)$, more positive attitude $(b=1.33 ; 95 \%$ $\mathrm{CI}=0.35$ to $2.30 ; \mathrm{p}=0.008)$, stronger perceived behavior control $(\mathrm{b}=1.21 ; 95 \% \mathrm{CI}=0.23$ to 2.20 ; $\mathrm{p}=0.016)$, better access to health service $(\mathrm{b}=1.59 ; 95 \% \mathrm{CI}=0.58$ to $2.59 ; \mathrm{p}=0.002)$, better health service quality $(\mathrm{b}=1.17 ; 95 \% \mathrm{CI}=0.22$ to $2.12 ; \mathrm{p}=0.016)$, and supportive subjective norm $(\mathrm{b}=2.07$; $95 \% \mathrm{CI}=1.12$ to $3.01 ; \mathrm{p}<0.001$ ). It was also indirectly affected by subjective norm, social culture, education, education, and access to health service.

Conclusion: Male surgical contraceptive method use is directly affected by age, knowledge, intention, attitude, perceived behavior control, access to health service, health service quality, and subjective norm. It is indirectly affected by subjective norm, social culture, education, education, and access to health service.
\end{abstract}

Keywords: male, contraceptive method, use, determinants, path analysis

\section{Correspondence:}

Bettya Kartikasari. Masters Program in Public Health, Universitas Sebelas Maret. Jl. Ir. Sutami 36A, Surakarta 57126, Central Java, Indonesia. Email: bettyakartikasari21@gmail.com.

Mobile: +6285817606484 .

\section{BACKGROUND}

Today's global problems are one of them caused by the growth of the world population that continues to increase. Birth rates in some countries have increased considerably, thus affecting a country's socioeconomic conditions in general and the mater- nal and child health conditions in particular (Sahilemichael, et al, 2015). Indonesia is one of the fifth most populous countries in the world where the population growth rate is still relatively high. If the growth rate is not controlled, it will further reduce the 
quality of a healthy and prosperous family for the people of Indonesia.

Increasing the rate of population growth can be controlled through the form of contraceptive services, namely the Family Planning Program. Family planning programs are part of effective government policies for efforts to control population rates, maternal and child health, and realize increased health development efforts. The target in this family planning program is fertile age couples (EFA). PUS is a married couple where wives are between the ages of 15 and 49 and are bound to legitimate marital relations (Indonesian Ministry of Health, 2014). The number of EFAs in Indonesia in 2017 is $37,338,265$, while active family planning participants are 23,606,218 (RI Ministry of Health, 2018).

Contraceptive methods are expected to be used effectively by fertile age couples (PUS), both women and wives and men or husbands as a means of birth control. Ideally, the use of contraceptives especially for couples (husband and wife) is a shared responsibility between men and women, so that the method chosen reflects the needs and desires of husband and wife without putting aside their reproductive rights. At least men need attention, care and participation in determining the use of contraception. However, the types of contraception and users of contraceptives are more dominated by women, while the use of male contraceptives is relatively less (BKKBN, 2018; Bhakti, 2008).

The percentage of male contraceptive use in Indonesia is still very low. Data from the Indonesian Ministry of Health 2018 shows that there are $1.75 \%$ of men contraceptive uses. In the Special Province of Yogyakarta men contraception use amounts to $6.26 \%$ (BKKBN, 2018). The form of male participation in family planning can be done directly and indirectly. Direct male participation is using one method of pregnancy prevention such as condoms, vasectomy, interrupted intercourse or periodic long methods. While the involvement of men indirectly, for example, men have a more positive attitude and make better decisions based on their attitudes and perceptions, and knowledge (Muhatiah, 2018; Ministry of Health, 2014; Wahyuni, 2013).

The use of male contraception is influenced by various factors. It includes: because the social, cultural, community, and family conditions that still consider men's participation are not yet important or not, knowledge and awareness and their families in family planning are still low and the limited acceptance and accessibility of men contraception services. The government with various existing resources seeks to improve men's equality in family planning, but the results are still not as expected (BKKBN, 2018; Wahyuni, 2013).

The low participation of men/husbands in family planning and reproductive health is influenced by factors that support both political, socio-cultural, and family support which are still low as a result of lack of knowledge of men and socio-cultural environment that considers family planning and reproductive health women. Beside the access factor, both information access and service access, seeing from access to information, men's information material is still very limited, as is the opportunity for men who are still lacking in obtaining information about family planning and reproductive health. Limitations are also seen in terms of services where facilities/ services that can accommodate family planning needs and male reproductive health are still very limited, and contraception for male is only limited to condoms and vasectomy (BKKBN, 2003).

Purwoko (2017) suggested that education is one of the factors that can influence 
knowledge and attitudes about contraceptive methods. Based on the proposed study conducted by author in Yogyakarta, the data were obtained that the number of EFA in Yogyakarta in 2017 was 492,745, the number of active family planning participants was 298,880 , and the number of men FP participants was 18,733 (6.26\%). This study focuses on examining social, economic, cultural determinants in male contraceptive use with the application of Theory of Planned Behavior and the PRECEDEPROCEED Planning Model.

The use of Theory of Planned Behavior in this study is based on the reason that decisions on contraceptive use are important decisions and are not decided suddenly and must be planned. Decisions in contraceptive use begin first of intention. Meanwhile, decisions on men contraceptive use are influenced by several factors that support and strengthen. These factors were accommodated in the PRECEDEPROCEED Planning Model.

\section{SUBJECTS AND METHOD \\ 1. Study design \\ This was an analytic observational study with a case control design. The study was carried out in Yogyakarta, Indonesia.}

\section{Population and sample}

The target population in this study was all men of reproductive age (15-49 years) who were married who lived in a family planning village in Yogyakarta. A sample of 200 men aged 15 to 49 years was selected for this study by fixed disease sampling.

\section{Study variables}

The dependent variable was male surgical contraceptive method use. The independent variables were age, knowledge, education, intention, attitude, perceived behavior control, subjective norm, social culture, access to health service, and health service quality.

\section{Data analysis}

The data were collected by questionnaire and analyzed by path analysis. Sample characteristics were described by univariate analysis. Bivariate analysis used Chi square. Multivariate analysis used path analysis to determine the direct and indirect effects of the relationships between study variables. Path analysis steps included model specification, model identification, model fit, parameter estimate, and model respecification.

\section{RESULTS \\ 1. Univariate analysis}

Table 1 showed sample characteristics. Table 1 showed that most of the sample was at age $<31$ years $(64.5 \%)$, had number children $\geq 3(53.5 \%)$, education $\geq$ senior high school (57\%), income $\geq$ Rp 1,300,000 (57\%), strong intention (62\%), strong PBC (58\%), positive attitude (53.5\%), and supportive subjective norm (61\%), high knowledge (58\%), supportive social culture (62\%), good quality of health service $(62.5 \%)$, ease of access to health service (61\%), and good quality of health sevice (62.5\%).

\section{Path analysis}

Figure 1 depicted the results of path analysis. Table 2 showed the results of path analysis. Table 2 showed that male surgical contraceptive method use was directly affected by older age $(b=1.50 ; 95 \% \mathrm{CI}=$ 0.54 to $2.46 ; \mathrm{p}=0.002$ ), better knowledge $(b=1.48 ; 95 \% \mathrm{CI}=0.48$ to $2.49 ; \mathrm{p}=0.004)$, stronger intention $(b=1.10 ; 95 \% \mathrm{CI}=0.15$ to $2.06 ; \mathrm{p}=0.24)$, more positive attitude $(b=1.33 ; 95 \% \mathrm{CI}=0.35$ to $2.30 ; \mathrm{p}=0.008)$, stronger perceived behavior control $(b=$ $1.21 ; 95 \% \mathrm{CI}=0.23$ to $2.20 ; \mathrm{p}=0.016)$, better access to health service $(b=1.59$; 95\% CI $=0.58$ to $2.59 ; \mathrm{p}=0.002$ ), better health service quality $(b=1.17 ; 95 \% \mathrm{CI}=$ 0.22 to $2.12 ; \mathrm{p}=0.016$ ), and supportive 
subjective norm $(b=2.07 ; 95 \% \mathrm{CI}=1.12$ to 3.01; $\mathrm{p}<0.001)$.
It was also indirectly affected by subjective norm, social culture, education, education, and access to health service.

Table 1. Sample characteristics

\begin{tabular}{|c|c|c|}
\hline Variable & $\mathbf{n}$ & $\%$ \\
\hline \multicolumn{3}{|l|}{ Age } \\
\hline$<31$ years & 129 & 64.5 \\
\hline$\geq 31$ years & 71 & $35 \cdot 5$ \\
\hline \multicolumn{3}{|l|}{ Number of children } \\
\hline$<3$ & 93 & 46.5 \\
\hline$\geq 3$ & 107 & 53.5 \\
\hline \multicolumn{3}{|l|}{ Income } \\
\hline$<\operatorname{Rp} 1,300,000$ & 86 & 43.0 \\
\hline$\geq \mathrm{Rp} 1,300,000$ & 114 & 57.0 \\
\hline \multicolumn{3}{|l|}{ Education } \\
\hline$<$ Senior high school & 86 & 43.0 \\
\hline$\geq$ Senior high school & 114 & 57.0 \\
\hline \multicolumn{3}{|l|}{ Knowledge } \\
\hline Low & 84 & 42.0 \\
\hline High & 116 & 58.0 \\
\hline \multicolumn{3}{|l|}{ Attitude } \\
\hline Negative & 93 & 46.5 \\
\hline Positive & 107 & 53.5 \\
\hline \multicolumn{3}{|l|}{ Socio-cultural } \\
\hline Not supporting & 76 & 38.0 \\
\hline Supporting & 124 & 62.0 \\
\hline \multicolumn{3}{|c|}{ Access to health service } \\
\hline Difficult & 78 & 39.0 \\
\hline Easy & 122 & 61.0 \\
\hline \multicolumn{3}{|c|}{ Quality of health service } \\
\hline Poor & 75 & 37.5 \\
\hline Good & 125 & 62.5 \\
\hline \multicolumn{3}{|l|}{ Subjective norm } \\
\hline Weak & 78 & 39.0 \\
\hline Strong & 122 & 61.0 \\
\hline \multicolumn{3}{|l|}{ PBC } \\
\hline Weak & 84 & 42.0 \\
\hline Strong & 116 & 58.0 \\
\hline \multicolumn{3}{|l|}{ Intention } \\
\hline Weak & 76 & 38.0 \\
\hline Strong & 124 & 62.0 \\
\hline \multicolumn{3}{|l|}{ Male contraceptive use } \\
\hline No & 150 & 25.0 \\
\hline Yes & 50 & 75.0 \\
\hline
\end{tabular}


Indonesian Journal of Medicine (2018), 3(2): 89-98

https://doi.org/10.26911/theijmed.2018.03.02.05

\section{$\frac{\text { DISCUSSION }}{\text { 1. The effect of intention on the use of }}$ male contraceptive}

The results of this study indicated that there was a direct and positive effect of intention on male contraceptive use in Yogyakarta. Stronger intention increased the use of male contraceptive. The results of this study was supported by Cristiani, et al. (2017) which stated that goals and intentions affected the decision to use the Long-Term Contraception Method.

Ajzen (2005) stated that intention was formed from attitudes on subjective norms, and perceived behavioral control possessed by an individual on a behavior. The intention to behave (behavioral cognitive) was a construct that showed a person's psychological (cognitive) readiness to perform a behavior. The intention to behave can also be understood as a plan or conscious decision to conduct a behavior. Until now, male contraceptive use was still very low, men who did not use contraception and wanted to use it must be initiated first by intention or a plan to use the contraception, rather than deciding to use the contraception in a sudden. The stronger the intention, the higher the chance to conduct a behavior (Murti, 2018).

\section{The effect of attitude on the use of male contraceptive}

The result this study showed that there was a positive and direct effect of attitude on men's contraceptive use in the family planning village in Yogyakarta. Attitude variable was influenced by subjective norm. Positive attitude affect increased contraceptive use. The result of this study was supported by Wahyuni et al. (2013), which stated that there was a significant and positive relationship between attitude and male participation in contraceptive use.

Attitude was the tendency of a person to respond, assess or express in the form of beliefs, feelings, or behavior towards an idea, event or situation that was socially important. Attitudes included situations where individuals have ambivalent judgments about an object, namely having positive or negative attitude to the same object (Murti, 2018).

Individual attitude toward behavior were obtained from beliefs about the consequences caused by behavior (behavioral belief). Someone who believed that a behavior can produce a positive outcome, then the individual would have a positive attitude and vice versa (Ajzen, 2005 via Sulaeman, 2016). Men who have a positive attitude toward contraceptive use were more likely to use contraception (Wetsons, 2018).

3. The effect of subjective norm on the use of male contraceptive

The result of this study showed that there was a direct and positive effect of subjective norm on male contraceptive use in the family planning village in Yogyakarta. Strong subjective norm increased positive attitudes toward male contraceptive use. The results of this study were supported by Wahyuni et al. (2013), which stated that there was a significant effect of attitude on participation in family planning because good attitudes also influenced subjective norms.

In various countries, socio-economic factors and cultural factors determined the family size norm. Social demographic and psychosocial characteristics can influence family size desires at the individual level (Bertrand, 2017). Subjective norms were individual perceptions of existing social pressure to do or not conduct an individual behavior or opinion about rules or standards that exist in a social environment, especially those who were considered important by individuals such as friends, parents, neighbors, community leaders, 
religious leaders, and teachers (Murti, 2018).

Subjective norms have the motivation to follow people's views on the behavior they would do (normative belief). Individuals have confidence that certain individuals or groups would accept or not accept the actions they do. If individuals believed in the norm of the group, the individual would obey and shape the behavior that was in accordance with the group (Ajzen 2005 via Sulaeman, 2016).

This also applied to the behavior of men/husbands in using contraception, individuals felt that using male contraceptive was not a normal thing, they felt that they did not have to use men's contraceptive because of environmental stress, which allow men to not use the contraception (Wahyuni et al, 2015).

\section{The effect of knowledge on the use of male contraceptive}

The result of this study showed that there was a direct and positive effect of knowledge on male contraceptive use in Yogyakarta. Education indirectly affected male contraceptive use through knowledge. High education increase knowledge and increased the use contraception among male. The results of this study were supported by Temach et al. (2017) which stated that the level of knowledge among married men in Dangla city was low and educational status was an important predictor of knowledge about vasectomy.

Education was one of the factors that could influence knowledge and attitudes about contraceptive methods. People who were highly educated would give a more rational response than those who were less educated, they would also be more creative and more open to renewal efforts. Highlyeducated people can also adjust to social change. The higher the level of education of couples participating in family planning, the greater the husband and wife viewed their child as an important reason for family planning, so high level of education would increase the proportion of those who know and use contraception to limit the number of children (Tamrie, 2015; Mota, 2015; Purwoko, 2010).

\section{The effect of access to health ser- vice on the use of male contra- ceptive}

The result of this study showed that there was a direct and positive effect of access to health service on male contraceptive use in Yogyakarta. Access to health service also had an effect on health service quality. Therefore, it can be concluded that there was a positive and direct effect of access to services on contraceptive use through service quality variables. The easy access to services would further increase contraceptive use through good quality services. The result of this study was supported by research from Cristiani et al. (2017) which showed that from living factors, the access has a close relationship to the selection and use of long-term contraceptive methods.

Access to family planning services should not be hampered by demographic, social, cultural, organizational and language barriers (Wijono, 2009). This affordability was intended for men to obtain adequate information and satisfying family planning services (BKKBN, 2013). Community Health Center was the first choice to get a condom because it was free and the distance was close. The second was PLKB, because of the proximity of the officers and they could get more complete information. Whereas stores, stalls, and pharmacies were the third choice to get condoms because they were free to choose and other people would not know (BKKBN, 2008). 
Indonesian Journal of Medicine (2018), 3(2): 89-98

https://doi.org/10.26911/theijmed.2018.03.02.05

\section{The effect of perceived behavior control on the use of male contraceptive}

The result this study showed that there was a direct and positive effect of perceived behavioral control on male contraceptive use in family planning village in Yogyakarta. Perceived behavioral control was affected by education. Therefore, it can be concluded that the stronger the perceived behavioral control, the higher the use of contraception. The result of this study was supported by Budisantoso (2008), which stated that there was a relationship between $\mathrm{PBC}$ and male in contraceptive use.

PBC was a person's perception of easy or hard behavior. Perceived behavioral control was divided into internal control and external control (Murti, 2018). Internal control placed within theirselves which refered to the individual's perception of the extent to which he/she was able to control a behavior. Most internal controls were related to knowledge, skills, and abilities possessed by individuals when performing a behavior. Thus a person with a strong internal control location tend to have a strong perceived behavioral control (Cleverism, 2018 cit. Murti, 2018).

External control refered to the extent to which external factors could influence behavior. Such as acceptance, approval or support from family, friends and peer groups which could influence or control individuals to have a positive attitude to contraceptive use behaviors that would strengthen the intention to realize these behaviors. Behavior control was an individual's ability to control the extent to which a person was able to conduct a behavior. If an individual has a high self-control, then the behavior of not using contraception would be difficult to influence his/her personality. However, the behavior of not using contraception would easily become a lifestyle if individuals have low self-control (Tamrie, 2015).

7. The effect of quality of services on the use of male contraceptive

The result this study showed that there was a positive and direct effect of quality of health services on male contraceptive use. Therefore, it can be concluded that the higher the quality of health service, the more likely it was to use contraception. The result of this study was supported by Ekarini (2018) which stated that there was a meaningful relationship between the quality of service and family planning participation.

There were six components in service quality, namely contraceptive choices, information, technical abilities, interpersonal relationships, follow-up or continuity, and ease of service. In the framework of his theory, it was also mentioned that the impacts of service quality were clients' knowledge, clients' satisfaction, clients' health, contraceptive use, acceptance, and continuity (Bruce, 2010; Jain, 2009; BKKBN, 2009).

\section{The effect of social culture on the use of male contraceptive}

The result of this study showed that there was a positive and indirect effect of quality of health service on male contraceptive use through subjective norm. Therefore, it can be concluded that the stronger the social culture, the stronger the subjective norms and eventually would make someone to use contraception. The result of this study was supported by Sahin et al. (2008), which stated that culture has a great effect on the participation of men in family planning. Similar study conducted by Ekarini (2008) with the results that there was a sociocultural influence on family planning.

Culture was a belief in the truth that came from human knowledge so that it 
became a source of assessment in the view of human's life (Belda, 2017). Culture was an integrated pattern of things, referring to what was done and known by most people so that it brought many aspects of assessment of the conditions experienced by most societies. Trust in culture also influenced the type of contraception used. Contraceptive method such as condoms was perceived as contraceptive that was natural and in line with the religion and culture taught. Religious values can affect aspects of life because they were an important part of cultural values in the group (Buhling et al, 2014).

\section{REFERENCE}

Ajzen I (2005). Attitudes, Personality and Behavior, 2nd Edition. McGraw-Hill Professional Publishing, Berkshire, GBR

Belda SS (2017). Modern contraceptive utilization and associated factors among married pastoralist women in Bale Eco-Region, Bale Zone, South East Ethiopia. BMC Health Services Research. 17(1): 194

Bertrand (2017). Kerangka pikir konseptual permintaan KB Serta Dampak Pada Fertilitas. Dalam: BKKBN. Peningkatan Akses dan Kualitas Pelayanan KB. BKKBN. Bandung.

Bhakti SM (2008). Analisis faktor-faktor yang berpengaruh terhadap partisipasi pria dalam keluarga berencana di Kecamatan Selo Kabupaten Boyolali. Tesis. Universitas Diponegoro.

BKKBN (2003). Peningkatan partisipasi pria dalam keluarga berencana dan kesehatan reproduksi. Jakarta

(2005). Peningkatan partisipasi pria dalam KB dan KR. Jakarta

(2008). Faktor-faktor sosial budaya yang mempengaruhi pemakaian kontrasepsi mantap wanita (MOW) dan kontrasepsi mantap pria (MOP) di Jawa Barat dan Nusa Tenggara Barat, Kerjasama LDUI-PULDU BKKBN. Jakarta

(2009). Studi gender peningkatan peran pria dalam penggunaan kontrasepsi di DKI. Kerjasama Pusat Kajian Pembangunan Universitas Atmajaya. Jakarta.

(2018). Gender dalam Program KB dan KR. http://gemapria.bkkbn.go.id/artikelo2-21.html diaksesJuli 2018 (2013). Pengayoman medis keluarga berencana. Jakarta

(2018). Gender dalam program KB dan KR. http://gemapria.bkkbn.go.id/artikelo2-21.htmldiaksesJuli 2018

Bruce J (2010). Fundamental elements of the quality of care, a simple frams studies in family planning. BMC Health Services Research. 17(1): 194

Cristiani C, Diah C, Martono B (2017). Faktor-faktor yang mempengaruhi pemakaian metode kontrasepsi jangka panjang (MJKP) Provinsi Jawa Tengah. Serat-Acitya-Jurnal Ilmiah Untag Semarang. 3(1): 74-84

Ekarini SMB (2008). Analisis faktor-faktor yang berhubungan terhadap partisipasi pria dalam keluarga berencana di Kecamatan Selo Kabupaten Boyolali. Tesis. Universitas Diponegoro Semarang.

Jain A (2009). Fertility reduction and the quality of the planning service. studies in family plannin. Journal of Health Communication. 4(4): 242

Kementerian Kesehatan Republik Indonesia (2014). Situasi dan analisis keluarga berencana. Jakarta: Pusat Data danInformasi

Mota K (2015). Unmeet need of long acting and permanent family planning methods among women in the reproductive age group in Shashemene 
Indonesian Journal of Medicine (2018), 3(2): 89-98

https://doi.org/10.26911/theijmed.2018.03.02.05

Town, Oromia Region, Ethiopia: A Cross Sectional Study. BMC Women's Health. 15(1): 51

Murti B (2018). Prinsip dan metode riset epidemiologi edisi keempat. Surakarta: BintangFajar Offset

Murti B (2018). Prinsip dan metode riset epidemiologi edisi keempat. Surakarta: Bintang Fajar Offset.

Purwoko (2017). Penerimaan vasektomi dan sterilisasi tuba. Tesis. Fakultas Kedokteran Undip. Semarang

Sahilemichael A. et al. (2015). Determinant of long acting reversible contraceptives use among child bearing age women in Dendi District, Western Ethiopia. J Women's Health Care. 4(4): 242

Sulaeman ES (2016). Pembelajaran model dan teori perilaku kesehatan. Konsep dan Aplikasi. Surakarta: UNS PRESS

Tamrie YE (2015). Determinants of long acting reversible contraception method use among mothers in extended postpartum period, durame town, southern ethiopia: a cross sectional community based survey. Health. 7(1): 1315-1326

Temach AJ, Fekadu GA, Achamyeleh AA (2017). Educational status as determinant of men's knowledge about vasectomy in Dangila Town Administration, Amhara Region, Nortwest Ethiopia. Reprod Health. 14(1):54

Wahyuni NPDS, Suryani N, Murdani P (2013). Hubungan pengetahuan dan sikap akseptor KB Pria tentang vasektomi serta dukungan keluarga dengan partisipasi pria dalam vasektomi di Kecamatan Tejakula Kabupaten Buleleng. Jurnal Magister Kedokteran Keluarga. 1(1): 80-91

Wahyuni (2017). Pelayanan keluarga berencana. Jakarta: Salemba Medika

Wetson (2018). Para wanita mempercayai pasangan untuk menggunakan kontrasepsi pria. http://pikas.bkkbn.go.id diaksesbulanJuli 2018 